\title{
WHAT HAPPENS WHEN YOU TREAT SEPTIC CEREBRAL EMBOLI WITH INTRAVENOUS THROMBOLYTIC TREATMENT? A CASE REPORT
}

\author{
Gülsüm SARUHAN, Ayse GÜLER, Hadiye ŞíRİN, Neşe ÇELEBISOY \\ Ege University Faculty of Medicine, Department of Neurology, İzmir, Turkey
}

\begin{abstract}
Infective endocarditis (IE) is the infection of the endocardial surfaces of the heart and intracardiac foreign bodies, and is caused by various microorganisms such as bacteria, fungus and viruses. Most common findings of IE include cardiac murmur, splenomegaly, Osler nodes, splinter hemorrhages, and Janeway lesions. Here, we aimed to present a IE case which was misdiagnosed as thromboembolic stroke, treated with intravenous (IV) thrombolytic treatment and developed multiple cerebral and cerebellar hemorrhages. A 35-year-old man with a history of diabetes mellitus (DM) and hypertension (HT) was admitted to our clinic with multiple cerebral and cerebellar hemorrhages. It was found out that the patient was given an antibiotic treatment due to high fever $\left(39-40{ }^{\circ} \mathrm{C}\right)$ and pharyngitis two weeks before admission to our clinic, and a week later he developed right side weakness. As computerised tomography (CT) and diffusion-weighted magnetic resonance imaging (MRI) were normal at the clinic the patient applied with right sided weakness, he was diagnosed with acute ischemic stroke and was given intravenous thrombolytic treatment-alteplase (IV rTPA). Patient was referred to our clinic due to persistent fever, clinical worsening and multiple cerebral and cerebellar hemorrhages in follow-up CT scan. The patient was referred to the Cardiology clinic with the preliminary diagnosis of infective endocarditis. Echocardiography (ECO) showed a thrombotic vegetation measuring $1.1 \times 0.7$ centimeters (cm) on the anterior mitral valve, and transoesophageal ECO showed a thrombotic vegetation measuring $1.9 \times 0.9$ on the mitral valve. The patient was referred to Infctious Diseases clinic for initiation of antibiotherapy, and Cardiovascular Surgery clinic regarding the need for surgery. Yet, as the surgery required high-dose heparin application, an operation was not performed. After the treatment, hemorrhage areas were seen to be regressed in follow-up brain CT scan. While evaluating patients who admit to the emergency with high fever and neurological deficits, septic embolism should also be kept in mind at the first visit and imaging methods should be used for further evaluation.
\end{abstract}

Keywords: Endocarditis, septic embolism, thrombolytic treatment.

\footnotetext{
Address for Correspondence: Gülsüm Saruhan, M.D. Ege University Faculty of Medicine, Department of Neurology, İmir, Türkiye. Phone: +90 $2323434343 \quad$ E-mail: drgulsumsaruhan@gmail.com

$\begin{array}{ll}\text { Received: } 08.12 .2019 & \text { Accepted: } 22.02 .2021\end{array}$

ORCID IDs: Gülsüm Saruhan 0000-0003-2498-6129, Ayşe Güler 0000-0003-4465-3743, Hadiye Şirin 0000-0003-0262-3706, Neşe Çelebisoy 0000-00034861-0249.

Please cite this article as following: Saruhan G, Güler A, Şirin H, Çelebisoy N. What happens when you treat septic cerebral emboli with intravenous thrombolytic treatment? A case report. Turkish Journal of Cerebrovascular Diseases 2022; 28(1): 63-67. doi: 10.5505/tbdhd.2021.31549
} 


\title{
İNFEKTIF ENDOKARDITE BAĞLI SEPTIK EMBOLIDE İNTRAVENÖZ TROMBOLITIK TEDAVİ UYGULARSAK
}

\author{
NE OLUR? OLGU SUNUMU
}

öz

İnfektif endokardit (İE), endokardın bakteriyel, viral veya fungal mikroorganizmalara bağlı gelişen enfeksiyonudur. Tipik bulguları üfürüm, splenomegali, osler nodülleri, splinter hemoraji, janeway lezyonlarıdır. Bu yazıda ateş yüksekliği sonrasında akut inme ile prezente olan IV rtPA uygulanan multipl serebral-serebellar hemoraji gelișen bir İE olgusunun sunulması amaçlanmıştır. 35 yaşında bilinen DM ve HT öyküsü olan erkek hasta multipl serebral ve serebellar hemoraji nedeni ile kliniğimize yatırıldı. Öyküsünde 2 hafta önce ateş yüksekliği (39-40 derece) gelişmesi üzerine farenjit tanısı ile antibiyotik tedavisi aldığı, ateș yüksekliğinden 1 hafta sonra sağ yan güçsüzlüğü geliştiği öğrenildi. Sağ yan güçsüzlüğü ile başvurduğu merkezde çekilen Beyin Bilgisayarlı Tomografi (BT) ve Beyin Magnetik Rezonans Görüntüleme (MRG) normal saptanan hastaya akut iskemik inme tanısı ile İntravenöz-Alteplaz (IV rtPA) uygulanmış. Çekilen kontrol beyin BT de multipl serebral ve serebellar hemoraji odakları saptanması ve hastanın nörolojik skorunda kötüleșme gelișmesi üzerine hastanemize sevk alındı. Ateş yüksekliği etyolojisi net aydınlatılamamış olan ve multipl hemorajik odağı olan hastada infektif endokardite sekonder septik emboli düşünülerek kardiyoloji tarafından ekokardiografi (EKO) yapıldı. EKO sonucunda mitral kapak anteriorunda 1,1 x $0.7 \mathrm{~cm}$ vejetasyon izlenmesi üzerine uygulanan Transözefageal EKO de 1,9 x $0,9 \mathrm{~cm}$ vejetasyon saptand. Enfeksiyon hastalıkları tarafından antibiyotik tedavisi düzenlendi. Kalp Damar Cerrahisine operasyon açısından danışıldı. Operasyon sırasında yüksek doz heparin kullanımı gerekeceği için hematom rezorpsiyonuna kadar operasyon planlanmadı. İzleminde ateş yüksekliği olmayan kontrol EKO larında vejetasyon boyutlarında küçülme izlenen hastanın izlem kranial BT lerinde hemorajilerinde rezorpsiyon izlendi. Acil servise yüksek ateș ve nörolojik defisit ile başvuran hastalar değerlendirilirken, septik embolizm öncelikle akla getirilmelidir ve ileri inceleme için görüntüleme yöntemleri kullanılmalıdır.

Anahtar Sözcükler: Endokardit, septik emboli, trombolitik tedavi.

\section{INTRODUCTION}

Infective endocarditis (IE) is an infection of the endocardial surface of the heart and intracardiac foreign bodies (1), highly mortal disease $(1,2)$ is caused by microorganisms such as bacteria, fungi and viruses. Risk factors for IE include cardiac factors (history of prior IE, presence of a prosthetic valve or a cardiac device, history of a valvular or congenital heart disease) and noncardiac factors (intravenous drug use, indwelling intravenous catheter, immunosuppression, or a recent dental or surgical procedure) (1-5). Despite the fact that IE mortality rates have been reduced in the last 30 years, mortality rate is still around $20-25 \%$ despite the appropriate treatment. In this article, it is aimed to present a patient who had no diseases other than diabetes mellitus (DM) and hypertension (HT); who was not considered as an IE patient in the initial diagnosis, misdiagnosed as thromboembolic stroke and given intravenous (IV) thrombolytic treatment.

\section{CASE REPORT}

A 35-year-old man presented our hospital with a sudden onset of right side weakness and lethargy. His medical history included hypertension and diabetes mellitus. We learned that 2 weeks before admission to our clinic, he was treated with antibiotics due to high fever $\left(39-40^{\circ} \mathrm{C}\right)$ and developed right side weakness 1 week after. Patient applied to another hospital with these findings and brain diffusion-weighted magnetic resonance image (MRI) and the blood tests were normal (Figure 1). The patient was diagnosed as acute ischemic stroke and was given intravenous thrombolytic treatment-alteplase (IV rTPA).

The patient was referred to our clinic one week after the thrombolytic treatment due to persistant fever and clinical worsening. In our clinic, neurological examination showed conscious stupor, global aphasia, right hemiparesis (4/5), and positive right pathologic reflex on the right side. The patient's fever was measured as $36.9^{\circ} \mathrm{C}$ and heart rate was 80 per minute. His C-reactive protein level was $4,6 \mathrm{mg} / \mathrm{dl}$, leukocyte level was $18,000 \mathrm{yL}$, and haemoglobin A1c level was 10,5 \%. Ultrasonography of the abdomen showed hepatosteatosis. Multiple hemorrhages were seen in brain tomography on bilateral cerebellar, bilateral frontal, right occipital areas, and on basal ganglia (Figure 2).

All the laboratory findings including platelet count, prothrombin time, partial thrombin time, antithrombin III level, antinuclear antibody (ANA), lupus anticoagulant antibody, anticardiolipin 


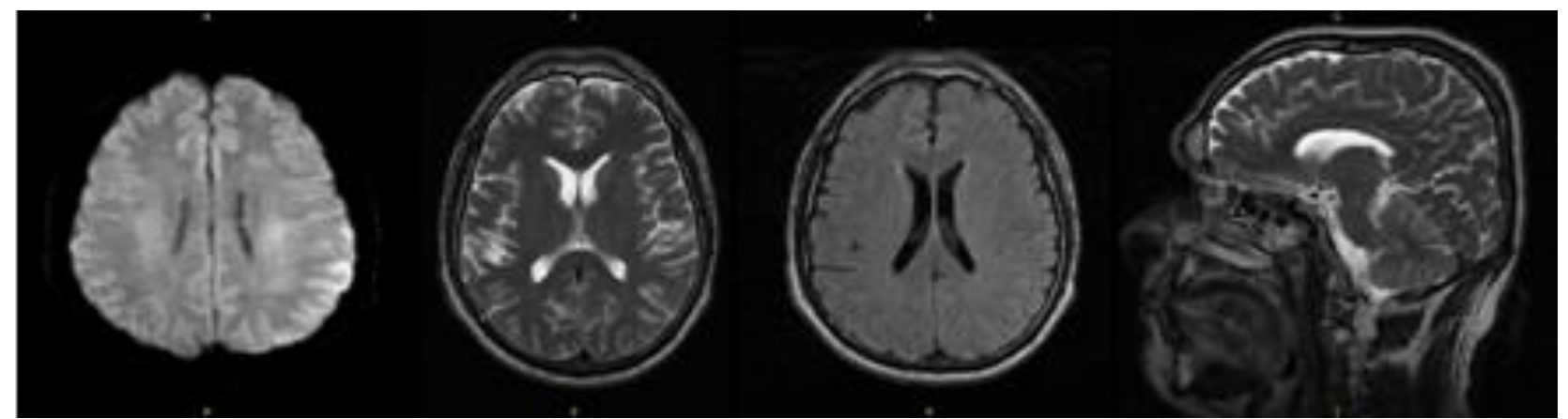

Figure 1. Normal brain MRI before the IV rTPA.

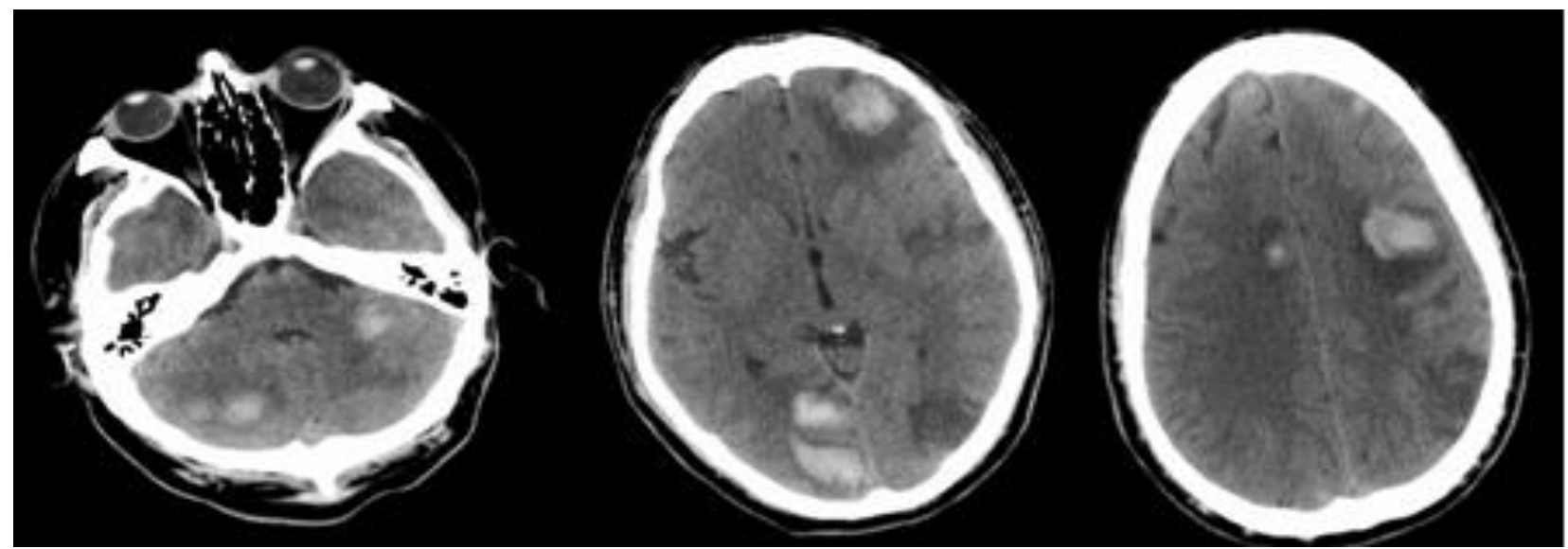

Figure 2. Haemorrhagic areas seen in brain CT.

antibody, antineutrophil cytoplasmic antibodies, anti-Sjogren syndrome-related antigen type A or B, factor $\mathrm{V}$, Leiden gene, protein $\mathrm{C}$ activity, protein $\mathrm{S}$ activity were normal as well.

The patient was referred to the Cardiology clinic with the preliminary diagnosis of infective endocarditis. Echocardiography (ECO) showed a thrombotic vegetation measuring $1.1 \mathrm{x} \quad 0.7$ centimeters $(\mathrm{cm})$ on the anterior mitral valve. Transoesophageal ECO showed a vegetation measuring $1.9 \times 0.9 \mathrm{~cm}$ of on the mitral valve. The patient was referred to Cardiovascular Surgery (CVS) clinic regarding the need for surgery. Yet, as the surgery required high-dose heparin application, and as the patient had haemorrhagic areas, the operation was not performed. The patient was then referred to Infectious Diseases clinic for the initiation of antibiotic treatment, and gentamycin 3x80 mg for 2 weeks and crystallized penicillin G $6 \times 4$ million IU for 6 weeks was recommended. Follow-up brain MRI was performed at the hospitalization, which revealed multiple infarction areas and multifocal hemorrhages in both cerebral and cerebellar parenchyma (Figure 3).

The blood culture test of the patient showed no growth. After 6 weeks of antibiotic treatment, the control ECO showed a reduced vegetation size of $0.5 \times 0.3 \mathrm{~cm}$. CRP and leukocyte levels were normal in follow-up blood tests. Hemorrhage areas were seen to be regressed in follow-up brain CT scan. As the neurological examination was normal, patient was given an cerebrovascular diseases outpatient clinic appointment in our Neurology clinic and discharged from hospital. Informed consent was obtained the patient for this report.

\section{DISCUSSION AND CONCLUSION}

Although its diagnosis and treatment options showed development in the recent years, IE still has a high mortality rate. IE is an infection in endocardial surface of the heart and intracardiac foreign bodies (intracardiac device, pacemaker, etc.) exposed to blood circulation in the heart (13 ), which is caused by various microorganisms such as bacteria, fungi and viruses. Vegetations 


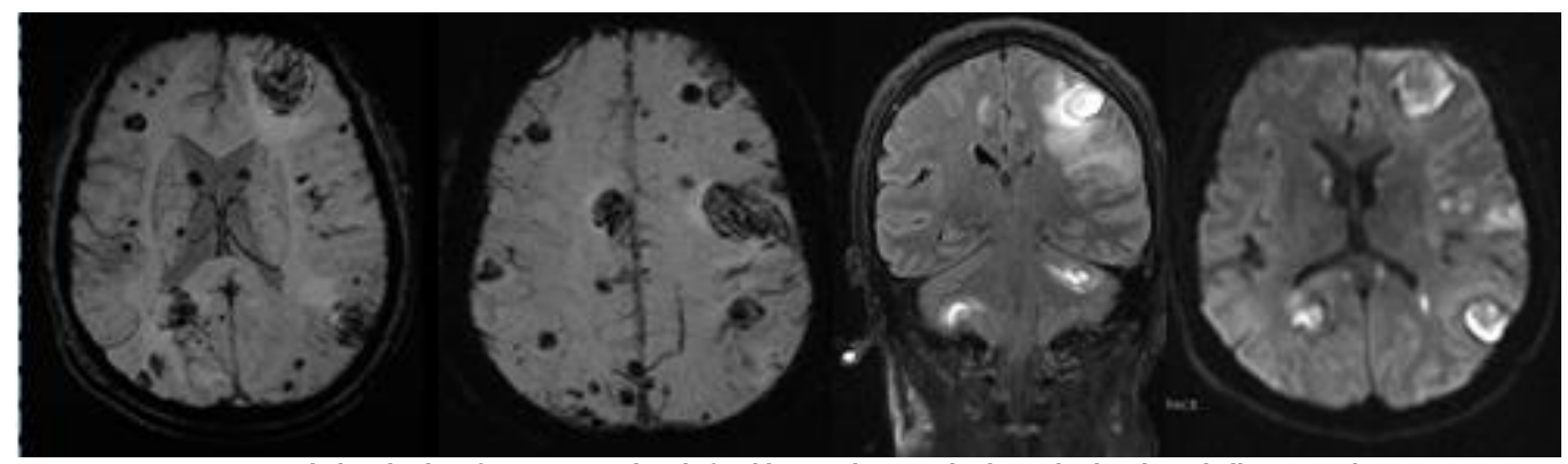

Figure 3. Brain MRI revealed multiple infarct areas and multifocal hemorrhages in both cerebral and cerebellar parenchyma.

are the characteristic lesions which include of platelet, fibrin, microorganism and inflammatory cells. Vegetations are able to cause valvular dysfunction, ulcers and abscesses. These lesions are mostly located on the mitral and aortic valve. The most prevalent etiological factors incluse Staphylococcus Aureus and Streptoccocus viridans $(1,6)$.

Anthony E et al. reported a case of a 27 yearold who had Haemophilus parainfluenzae endocarditis and secondary cerebral embolism caused by endocarditis (7).

IE is mostly seen in individuals aged between 30 and 60 years. Ratio of male/female is $1.7 / 1$. Williams Osler, who set the diagnostic criteria of IE, reported that "Infective endocarditis is the malignant disease of the Infectious Diseases". Predisposing factors include; rheumatic heart disease, prosthetic valve, congenital heart diseases, dental procedures and IV drug addiction $(1,6-8)$. Yet our patient had none of these predisposing factors in his history.

The most common symptoms are fever, anorexia and night sweats (8-10). In addition to these, cardiac murmur, splenomegaly, Osler nodules, splinter hemorrhages, Janeway lesions, systemic embolism and neurological complications may also be seen. Neurolgical findings are seen in \%20-40 of the IE cases. Other clinical findings include ischemic or haemorrhagic stroke, transient ischemic attack, silent cerebral embolism, symptomatic or asymptomatic infectious aneurysm, brain abscess, meningitis, toxic encephalopathy and seizures. The possibility of septic embolism secondary to IE should always be kept in mind in patients with chronic immune system disfunction (DM, HT, connective tissue disorders, etc.) who develop acute neurological findings following high fever, and it should not be forgotten that IV TPA treatment to this disease may have lethal consequences (8). One of the most lethal consequences of the IE is ischemic stroke. Yet, as it increases the risk of intracranial haemorrhagia, IV thrombolytic treatment is contraindicated in cerebral stroke due to IE.

In our case, infective endocarditis was not recognised at the first stage of the diagnosis on the first hospital our patient applied to, and intracranial haemorrhage was developed due to IV rTPA.

IE is a quite fatal disease if not treated appropriately (8). In recent years, innovations in diagnostic and therapeutic fields have contributed to the improvement of the IE prognosis. In case of a delayed diagnosis or absence of treatment, the mortality rates of IE are still quite high: IE's mortality rate in developed countries is $20 \%$ and $30 \%$ in our country. Antibiotics, antiaggregants, anticoagulants and surgery are recommended for the treatment of IE.

All in all, in patients who are admitted to the emergency with high fever and neurological deficits should also be considered as possible septic embolism at the first visit and imaging methods should be used for further evaluation (7, $9,10)$.

\section{REFERENCES}

1. Morris Nicholas A, et al. "Neurologic complications in infective endocarditis: identification, management, and impact on cardiac surgery." The Neurohospitalist 2014; 4(4): 213-222.

2. Ng CS, Mohamad S, Maskon O. Medical therapy of a leftsided native valve endocarditis with neurologic sequela. Saudi Med J 2015; 36(6): 743-746.

3. Asaithambi G, Malik MA, Adnan IQ. Thrombolysis for ischemic stroke associated with infective endocarditis: 
results from the nationwide inpatient sample. Stroke 2013; 44(10): 2917-2919.

4. Brownlee WJ, Anderson NE, Barber PA. Intravenous thrombolysis is unsafe in stroke due to infective endocarditis. Intern Med J 2014; 44(2): 195-197.

5. Ulu Kılıç A, Tütüncü E, Sarı S, et al. Embolic complications of infective endocarditis: report of two cases and review of national literature. Klimik Journal 2011; 24(3): 179-183.

6. Tversky S, Libman R, Schloss E, et al. Catastrophic intracranial hemorrhages after IV tPA in a patient with insidious onset of fever and back pain. Journal of Stroke and Cerebrovascular Diseases 2016; 25(5): e69-e70.

7. Anthony E, Duzenli AE, Dwyer J, et al. Haemophilus parainfluenzae endocarditis associated with maxillary sinusitis and complicated by cerebral emboli in a young man. Journal of Investigative Medicine High Impact Case Reports 2017; 5(2): 1-3.

8. Baddour LM, Wilson WR, Bayer As, et al. Infective endocarditis: diagnosis, antimicrobial therapy, and management of complications: a statement for healthcare professionals from the Committee on Rheumatic Fever, Endocarditis, and Kawasaki Disease, Council on Cardiovascular Disease in the Young, and the Councils on Clinical Cardiology, Stroke, and Cardiovascular Surgery and Anesthesia, American Heart Association: endorsed by the Infectious Diseases Society of America. Circulation 2005; 111(23): e394-e434.

9. Doolub G, Deanery S, Gloucester. Septic Cerebral Embolisation in Fulminant Mitral Valve Infective Endocaridtis. Case Rep Neurol 2015; 7(2):134-141.

10. Ong E, Mechtouff L, Bernard E, et al. Thrombolysis for stroke caused by infective endocarditis: an illustrative case and review of the literature. Journal of neurology 2013; 260(5): 1339-1342.
Ethics

Informed Consent: The authors declared that informed consent form was signed by the patient.

Copyright Transfer Form: Copyright Transfer Form was signed by the authors.

Peer-review: Internally peer-reviewed.

Authorship Contributions: Surgical and Medical Practices: GS, AG, HŞ, NÇ. Concept: GS, AG, HŞ, NÇ. Design: GS, AG, HŞ, NÇ. Data Collection or Processing: GS, AG, HŞ, NÇ. Analysis or Interpretation: GS, AG, HŞ, NÇ. Literature Search: GS, AG, HŞ, NÇ. Writing: GS, AG, HŞ, NÇ.

Conflict of Interest: No conflict of interest was declared by the authors.

Financial Disclosure: The authors declared that this study received no financial support. 